\title{
INHIBITOR OF THE TRANSCRIPTION FACTOR NF-кB, DHMEQ, ENHANCES THE EFFECT OF PACLITAXEL ON CELLS OF ANAPLASTIC THYROID CARCINOMA IN VITRO AND IN VIVO
}

\author{
V. V. PUSHKAREV ${ }^{1}$, D. V. STARENKI ${ }^{2}$, V. M. PUSHKAREV $V^{1}$, \\ O. I. KOVZUN ${ }^{1}$, M. D. TRONKO \\ ${ }^{1}$ State Institution V. P. Komisarenko Institute of Endocrinology and Metabolism, \\ National Academy of Medical Sciences of Ukraine, Kyiv; \\ e-mail: pushkarev.vm@gmail.com; \\ ${ }^{2}$ Department of Biochemistry, Medical College of Wisconsin, USA; \\ e-mail:dstarenki@mcw.edu
}

Anticancer drug paclitaxel (Ptx) effect on biochemical mechanisms, regulating apoptosis in anaplastic thyroid carcinoma cells, was studied. It was shown that in addition to apoptotic cell death, Ptx induces signaling cascades that ensure cell survival. Paclitaxel-induced activation of nuclear factor kappa B (NF- $\kappa B$ ) leads to an increase of some antiapoptotic proteins expression such as survivin, cIAP, XIAP. A novel NF- $\kappa B$ inhibitor, dehydroxymethylepoxyquinomicin (DHMEQ), was found to enhance cytotoxic effect of Ptx in anaplastic thyroid carcinoma cells. An enhancement of caspase-3 and -9 activation and PARP cleavage as well as the decreased levels of proteins-inhibitors of apoptosis were observed when cells were treated with a combination of both drugs. Mitochondria transmembrane potential $\left(\Delta \Psi_{m}\right)$ loss was observed at higher concentrations of Ptx and DHMEQ. NF- $\mathrm{B}$ inhibition also potentiates paclitaxel effect at tumors formed by xenotransplantation of FRO cells into mice. Tumor mass reduction, significantly different from the effects of each of the compounds alone, was observed in animals, treated with paclitaxel and NF- $\kappa B$ inhibitor. Thus, the combined use of paclitaxel and $N F-\kappa B$ inhibitor inhibits biochemical processes that contribute to the resistance of anaplastic thyroid carcinoma cells to paclitaxel action.

Key words: paclitaxel, thyroid, anaplastic cancer, apoptosis, NF-кB.

$\mathrm{P}$ aclitaxel (Ptx) is one of the most effective anticancer drugs commonly used to treat cancer patients [1, 2]. There are researches conducted on the possibility of its use for the treatment of patients with the thyroid cancer [3, 4]. Experimental data available indicate that in thyroid tumor cells Ptx activates not only the processes that cause cell death, but also the mechanisms that actively counteract to Ptx-induced apoptosis [3]. Therefore, studies aimed at finding methods of inactivation of biochemical mechanisms involved in the formation of tumor cells resistance to this anticancer drug are important.

Nuclear factor NF- $\kappa \mathrm{B}$ is the universal transcription factor that controls the expression of a variety of genes. Family of NF- $\kappa \mathrm{B}$ factors is involved in many signaling mechanisms that control the immune response, processes of proliferation, survival, differentiation, apoptosis, cell division and migration $[5,6]$. Dysregulation of NF- $\kappa \mathrm{B}$ functions leads to inflammation and is associated with many diseases, including cancer [7-10]. Moreover, NF-кB is considered as one of the major mediators linking chronic inflammation and malignant transformation of cells $[7,9,10]$. NF- $\kappa \mathrm{B}$ is constitutively active in most types of cancer, and many signaling pathways, involved in carcinogenesis, are accompanied by this factor activation [10, 11].

In mammalian cells NF- $\mathrm{B}$ family includes: p65 (RelA), RelB, c-Rel, p50/p105 (NF-kB1) and $\mathrm{p} 52 / \mathrm{p} 100(\mathrm{NF}-\mathrm{kB} 2)$. These proteins have a unique Nterminal Rel-homologous domain for hetero- or homodimers formation and DNA binding. C-terminal transactivation domain of p65, RelB and c-Rel functions as transcription activator when bound to p50 or $\mathrm{p} 52$. The most common form of NF- $\mathrm{BB}$ is a heterodimer consisting of p65 and p50. In most normal quiescent cells NF- $\mathrm{KB}$ dimers are bound and kept in cytoplasm by inhibitor kappa B (IкB), which masks the so-called nuclear localization sequence in NF- $\mathrm{KB}$ proteins. Currently five members of a family of $\mathrm{I} \kappa \mathrm{B}$ 
proteins were identified: $\mathrm{I} \kappa \mathrm{B} \alpha, \mathrm{I} \kappa \mathrm{B} \beta, \mathrm{I} \kappa \mathrm{B} \gamma, \mathrm{I} \kappa \mathrm{B} \varepsilon$ and

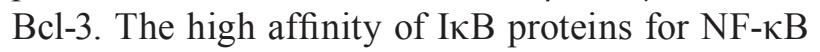
provides tight control of this signaling pathway activation. RelA (p65) was previously recognized as a potential oncogene $[5,6]$.

The NF- $\kappa \mathrm{B}$ activation in response to extracellular stimulation and intracellular stress events is mainly controlled by the canonical (classic) and non-canonical (alternative) signaling pathways. In particular, complex of kinase I $\mathrm{I} B$ (IKK), which is composed of two catalytic subunits IKK $\alpha$ (IKK1) and IKK $\beta$ (IKK2) and regulatory component NEMO (NF- $\kappa \mathrm{B}$ modulator; IKK $\gamma$ ) are involved in the control of the canonical pathway $[5,6,11]$.

The influence of nuclear factor NF- $\mathrm{KB}$ on apoptotic processes in tumor cells was intensively investigated in the recent years. It was shown that the factor activated a group of genes whose products suppressed apoptosis by caspases inhibiting [5]. In particular, it relates to gene family of proteins-inhibitors of apoptosis, which are capable of suppressing the activity of effector caspases, and the caspase-3 in the first place [12]. These include cIAP1, cIAP2, survivin, XIAP, and besides, these proteins may cause the second wave of NF- $\kappa \mathrm{B}$ activation, thus further enhancing the expression of antiapoptotic genes $[13,14]$. Since NF- $\kappa B$ plays an important role in antiapoptotic processes, causes chemo- and radioresistance of tumor cells $[5,15,16]$, it was expected that its inhibition would enhance the Ptx toxicity in tumors. Previous data showed that NF- $\kappa B$ suppression with DHMEQ inhibitor enhanced radiation-induced apoptosis in thyroid cancer cells [17].

The aim was to study the biochemical mechanisms of combined action of Ptx and a new inhibitor of nuclear factor NF- $\mathrm{BB}$, dehydroxymethylepoxyquinomicin (DHMEQ), on apoptotic processes in the anaplastic thyroid carcinoma cells and tumor xenotransplants.

\section{Materials and Methods}

Reagents. Polyclonal antibodies to caspases, PARP, p65 (RelA), IкB $\alpha$, survivin, cIAP-2, XIAP (X-linked inhibitor of apoptosis), phosphorylated proteins cRaf-1, IKK $\alpha$ and horseradish peroxidase conjugated second antibodies were from the "Cell Signaling Technology" (USA). Complexes of proteins with antibodies were visualized using ECL reagent (Amersham Life Science, UK). Paclitaxel was from "Wako Chemicals" company (Osaka, Japan). DHMEQ was kindly provided by Dr. K. Umezava
(Keio University, m. Yokohama, Japan). Stock solution of racemate DHMEQ $(10 \mathrm{mg} / \mathrm{mL})$ were prepared in DMSO and stored at $-20^{\circ} \mathrm{C}$.

Cell lines. Human anaplastic thyroid carcinoma cells FRO, ARO and mutARO (cell line with a mutated $N F-\kappa B I A$ encoding cytosolic protein inhibitor of NF- $\kappa B-I \kappa B \alpha$ ) were used. All cell lines were obtained from prof. V.A. Saenko and prof. S. Yamashita (Nagasaki University Graduate School of Biomedical Sciences, Nagasaki, Japan).

Conditions of culturing. Cells were grown in RPMI-1640 medium supplemented with 5\% fetal bovine serum (FBS) and the mixture of penicillin/ streptomycin $(100 \mathrm{U} / \mathrm{ml} / 100 \mu \mathrm{g} / \mathrm{ml}$, respectively), in a $5 \% \mathrm{CO}_{2}$ humidified atmosphere at $37^{\circ} \mathrm{C}$. After 2 days incubation, when the culture reached about $80 \%$ confluence, cells were washed twice with phosphate-buffered saline (PBS) $(\mathrm{pH} 7.4)$ at $37^{\circ} \mathrm{C}$, and a fresh medium was added to each dish. Cells were incubated for additional $24 \mathrm{~h}$, exposed to the drugs dissolved in dimethylsulfoxide (DMSO), and then collected at different time intervals. In control samples we added the same amount of DMSO. After incubation, cells were washed twice with cold PBS $\left(2{ }^{\circ} \mathrm{C}\right)$, containing sodium pyrophosphate and orthovanadate, collected in $1 \mathrm{ml}$ of PBS buffer and pelleted for $3 \mathrm{~min}$ at $200 \mathrm{~g}$ and $2{ }^{\circ} \mathrm{C}$. Preparation of cell lysates and Western blot analysis was performed as previously described [3]. Developed X-ray film was scanned using GelPro 3.1 software and normalized by $\beta$-actin amount in each lane.

Cell survival assay. Cultures were established in the 96-well flat-bottom microtiter plates (Nalge Nunc International, Tokyo, Japan) in RPMI 1640 containing 5\% FBS. Cell suspensions $(100 \mu 1, \sim 1000$ cells/well) were added to each well and incubated for $24 \mathrm{~h}$ before treatment. Ptx $(10 \mu \mathrm{l})$ and DHMEQ dissolved in DMSO (in control samples - DMSO only) were added to each well at increasing concentrations, six wells for each concentration. After incubation, a water-soluble tetrazolium salt-based assay (WST) was performed as follows: $11 \mu \mathrm{l}$ of the cell counting kit solution (CCK-8, Dojin, Osaka, Japan) were added to each well and incubated for $1 \mathrm{~h}$ at $37^{\circ} \mathrm{C}$. Optical density was read at $450 \mathrm{~nm}$ in a microplate reader.

Assessment of mitochondrial membrane potential. Changes in electrochemical potential of mitochondrial membrane were examined using flow cytometry analysis of cells stained with tetramethylrhodamine ethyl ester (TMRE, Molecular Probes, Eugene, OR), a cell-permeable dye accumulating 
in mitochondria with unaltered membrane potential [18]. Cells were harvested by trypsinization at the end of experimental protocol, and $1 \times 10^{5}$ cells were incubated with $100 \mathrm{ng} / \mathrm{ml}$ TMRE for $15 \mathrm{~min}$ at RT in HEPES-buffered saline ( $\mathrm{pH}$ 7.4) followed by the analysis with the FACScan $(20,000$ cells/sample). The fluorescence intensity of TMRE was monitored at $582 \mathrm{~nm}$ (FL-2).

Nude mouse xenograft model. Standards of experimental animals maintenance meet the essential requirements of Bioethics Committee to maintain and work with laboratory animals and the European Convention for the Protection of Vertebrate Animals used for experimental and other scientific purposes (Strasbourg, 1986).

FRO cells were grown in RPMI 1640 supplemented with $5 \%$ fetal bovine serum in a $5 \% \mathrm{CO}_{2}$ humidified atmosphere at $37^{\circ} \mathrm{C}$. Cells $\left(5 \times 10^{6}\right.$ cells per animal) resuspended in RPMI 1640 were injected s.c. into both flanks of 8-week-old female BALB/c nu/nu mice (Charles River, Japan, Tokyo), 9 animals per group. Animal weight was about $25 \mathrm{~g}$. Tumor sizes were measured each alternate day with callipers, and tumor volumes were calculated according to the formula: $a^{2} \times b \times 0.4$, where $a$ is the smallest tumor diameter and $b$ is the diameter perpendicular to $a$. Treatment with Ptx and DHMEQ started after the tumor size approached $100 \mathrm{~mm}^{3}$. Ptx (10 mg/kg/day) and DHMEQ $(8 \mathrm{mg} / \mathrm{kg} /$ day $)$ diluted in Cremophor EL (Sigma, USA), ethanol and PBS (pH 7.4) (1:1:1 $\mathrm{v} / \mathrm{v} / \mathrm{v} /$ ) were injected intraperitoneally (i.p.) daily for 7 days. Animals from the control group received vehicle injections. To determine the effect of low doses of Ptx on tumor growth, animals were treated with i.p. Ptx injections at a dose of $2 \mathrm{mg} / \mathrm{kg} /$ day daily for 20 days.

Statistical analysis. All data were expressed as a mean \pm SD or mean \pm SE. Differences between groups were examined for statistical significance using Student test. $P<0.05$ was considered indicating statistical significance.

\section{Results and Discussion}

Effect of Ptx on the components of NF- $\kappa B$ signaling cascade. Ptx enhances phosphorylation of IKK $\alpha$ kinase and thus activation of NF- $\kappa \mathrm{B}$, in 3 hours of cells incubation with the drug, with a maximum at 12 h (Fig. 1, A). A clear increase of IKK $\alpha$ phosphorylation was observed starting from $10 \mathrm{nM}$ of Ptx concentration (Fig. 1, B, C). At the same time a decrease of I $\mathrm{I} B \alpha$ content, due to its phosphoryla- tion by IKK $\alpha$ and degradation of this protein in proteasomes $[5,6]$, was observed. The amount of p65 (RelA) gradually increased starting from $5 \mathrm{nM}$ concentration of Ptx, reached a maximum at $10 \mathrm{nM}$ (1.5fold relative to control) and dropped to a level that is lower than the control with a further increase in drug concentration (Fig. 1, B, C ).

Thus, in anaplastic thyroid carcinoma cells Ptx initiates signaling mechanisms associated with the activation of NF- $\mathrm{KB}$.

Effect of Ptx and NF- $\kappa B$ inhibitor on the state of proteins involved in apoptosis. Study of Ptx and DHMEQ effect on the proteins involved in the apoptotic process showed that Ptx and DHMEQ enhance the activation of caspase-3, caspase- 9 and PARP cleavage. There was almost no activation of the main effector caspase- 3 in the control samples. In the presence of Ptx, and, in particular, NF- $\mathrm{KB}$ inhibitor cleavage of caspase-3 significantly increased (Fig. 2, $A, C$ ). The combination of both agents demonstrates an additive effect that exceeds the effects of individual compounds. The same pattern was observed in the study of caspase-9 activation, which represents the mitochondrial pathway of apoptosis (Fig. 2, A).

One of the evidences of caspases activation is partial proteolysis of their protein substrates including PARP, which splits under the caspase action into two fragments ( 89 and $24 \mathrm{kDa}$ ). PARP is useful for apoptosis quantify because its large fragment $(89 \mathrm{kDa})$ is close in size to the intact PARP (117 kDa), which makes it possible to observe simultaneously the decrease in the content of intact protein and increase of its large fragment. Fig. 2, $A, C$ shows intactness of PARP in control samples. Under the action of Ptx $89 \mathrm{kDa}$ fragment content is increased, in the presence of NF- $\mathrm{kB}$ inhibitor PARP further degrades and combined effect of both compounds gives the maximum effect.

To ascertain the specific mechanisms of antiapoptotic action of NF- $\mathrm{KB}$ we studied the expression of some antiapoptotic proteins. It is known that some proteins-inhibitors of apoptosis (cIAP1-2, XIAP, survivin), expression of which can be controlled by $\mathrm{NF}-\kappa \mathrm{B}$, are involved in the regulation of apoptosis. It was assumed that inhibition of NF- $\kappa B$ would lead to reduced expression of these proteins and, consequently, to enhancement of paclitaxel-induced apoptotic processes.

Fig. 2, $B, C$ shows that in the presence of Ptx, expression of these proteins in tumor cells increases significantly. In particular, it concerns cIAP2, the 
$A$

\begin{tabular}{llllll}
0 & 3 & 6 & 12 & 24 & $\mathrm{~h}$ \\
\hline & & & & &
\end{tabular}

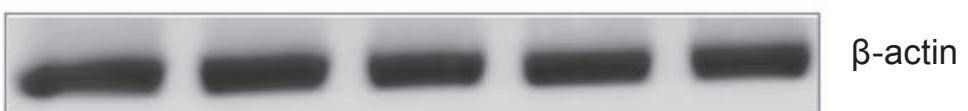

$B$
0
2.5
5
10
25 nM Ptx

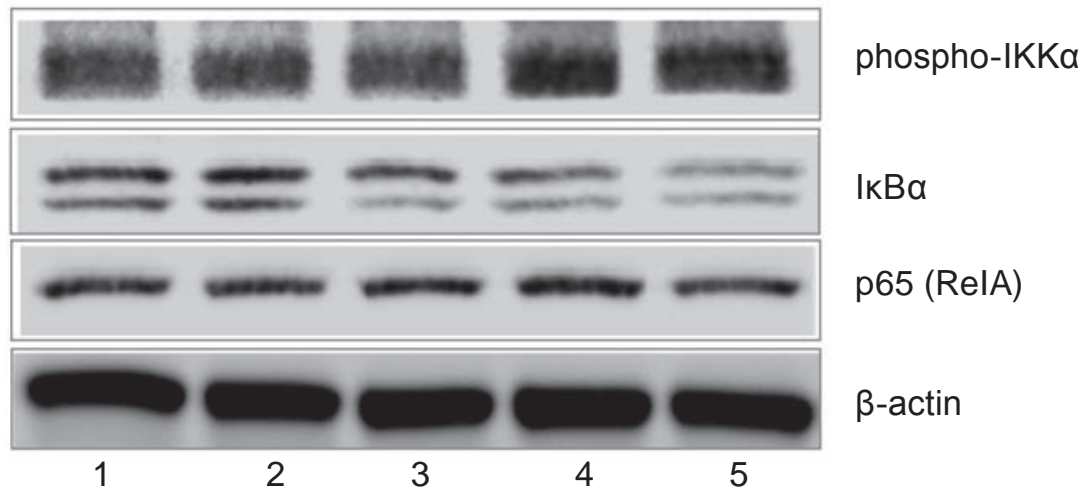

C
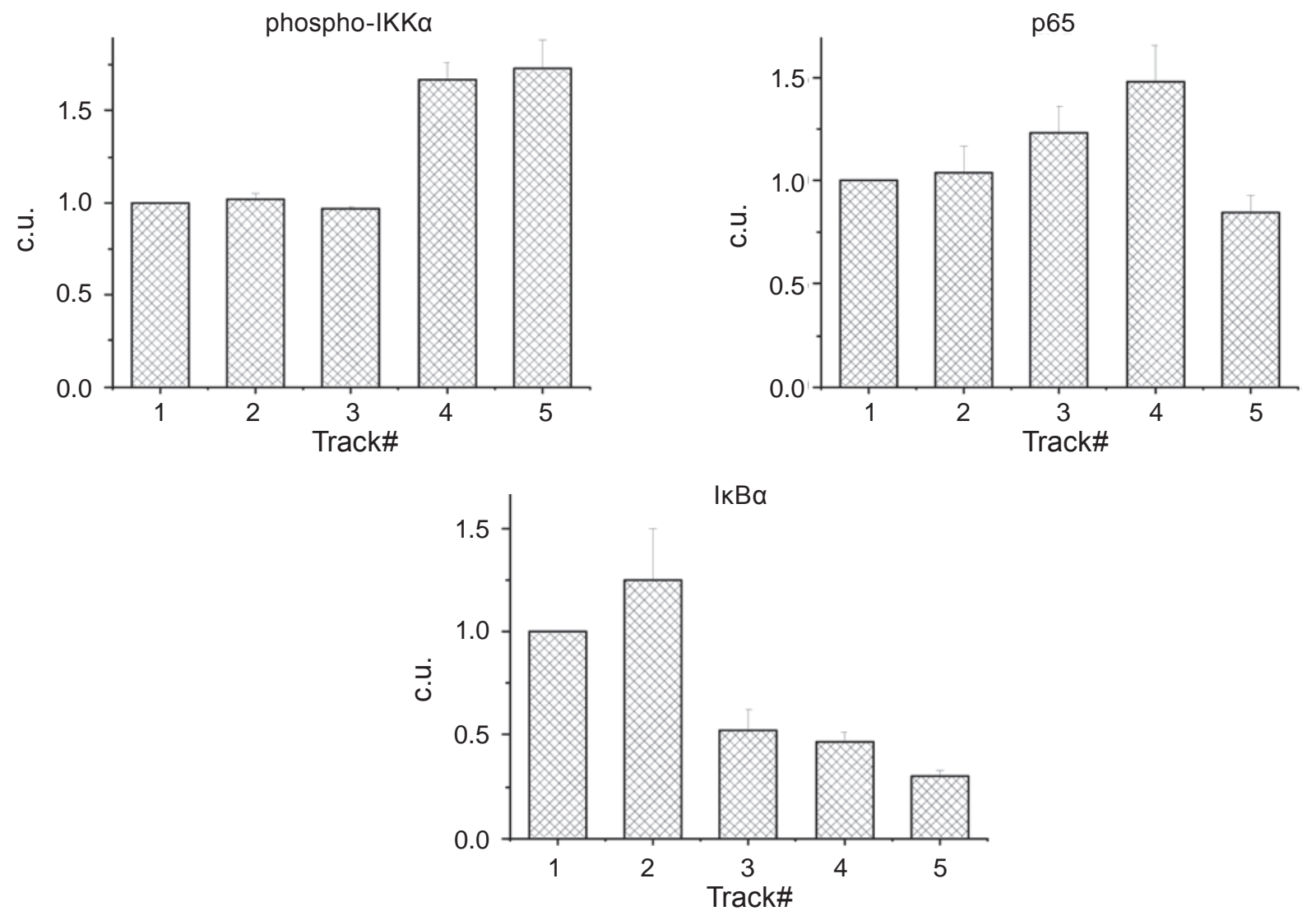

Fig. 1. Effect of paclitaxel upon activation and amount of the signaling cascade NF- $\kappa B$ components in FRO cells. Identification of proteins by Western blot analysis $(A, B)$ and $N F-\kappa B$ signaling cascade component contents diagrams (C) in FRO cell lysates after data normalization considering the $\beta$-actin content on the respective track. c.u. - conventional units. $M \pm S E, n=3$. 


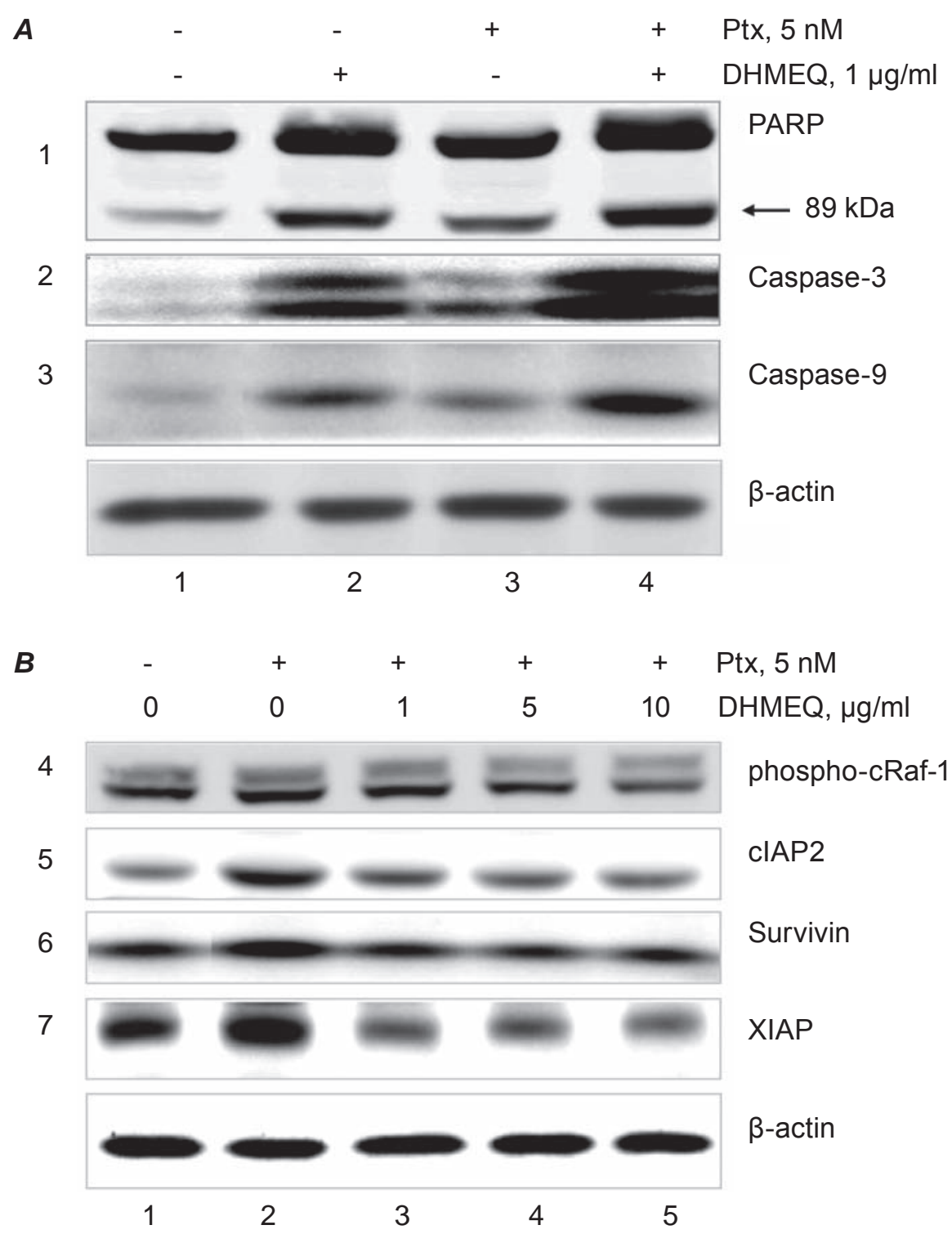

Fig. 2. The effect of the combined action of paclitaxel and NF- $\kappa B$ inhibitor on activation and content of proand antiapoptotic proteins in FRO cells. Identification of proteins by Western blot analysis $(A, B) . M \pm S E$, $n=3$

content of which at the Ptx action increased nearly 5 times. Thus, in tumor cells, the defense mechanisms opposed the proapoptotic processes induced by Ptx, are activated, which to some extent could neutralize apoptotic. Addition of DHMEQ to the incubation medium caused significant suppression of the apoptosis-inhibitors expression, especially of XIAP, the content of which is reduced to essentially lower level than in the control sample (Fig. 2, C).

Thus, NF- $\kappa \mathrm{B}$ directly or indirectly controls the expression of apoptosis inhibitors - cIAP2, XIAP and survivin in thyroid cancer cells. The combined action of Ptx and NF- $\kappa$ B inhibitor reduced the ex- pression of proteins-inhibitors of apoptosis that could enhance apoptotic processes in the cells of anaplastic thyroid carcinoma.

As shown earlier, signaling systems that counteract the proapoptotic effects of Ptx in the thyroid tumor cells were PI3K- and MAPK-dependent pathways [3]. Therefore, to clarify the mechanisms that enhance apoptosis in the presence of DHMEQ we studied activation of mitogen-activated protein kinases, namely, analyzed phosphorylation of one of the key protein of this cascade - cRaf-1. It can be seen that Ptx enhances cRaf-1 phosphorylation (Fig. 2, B, C). In the presence of increasing concen- 

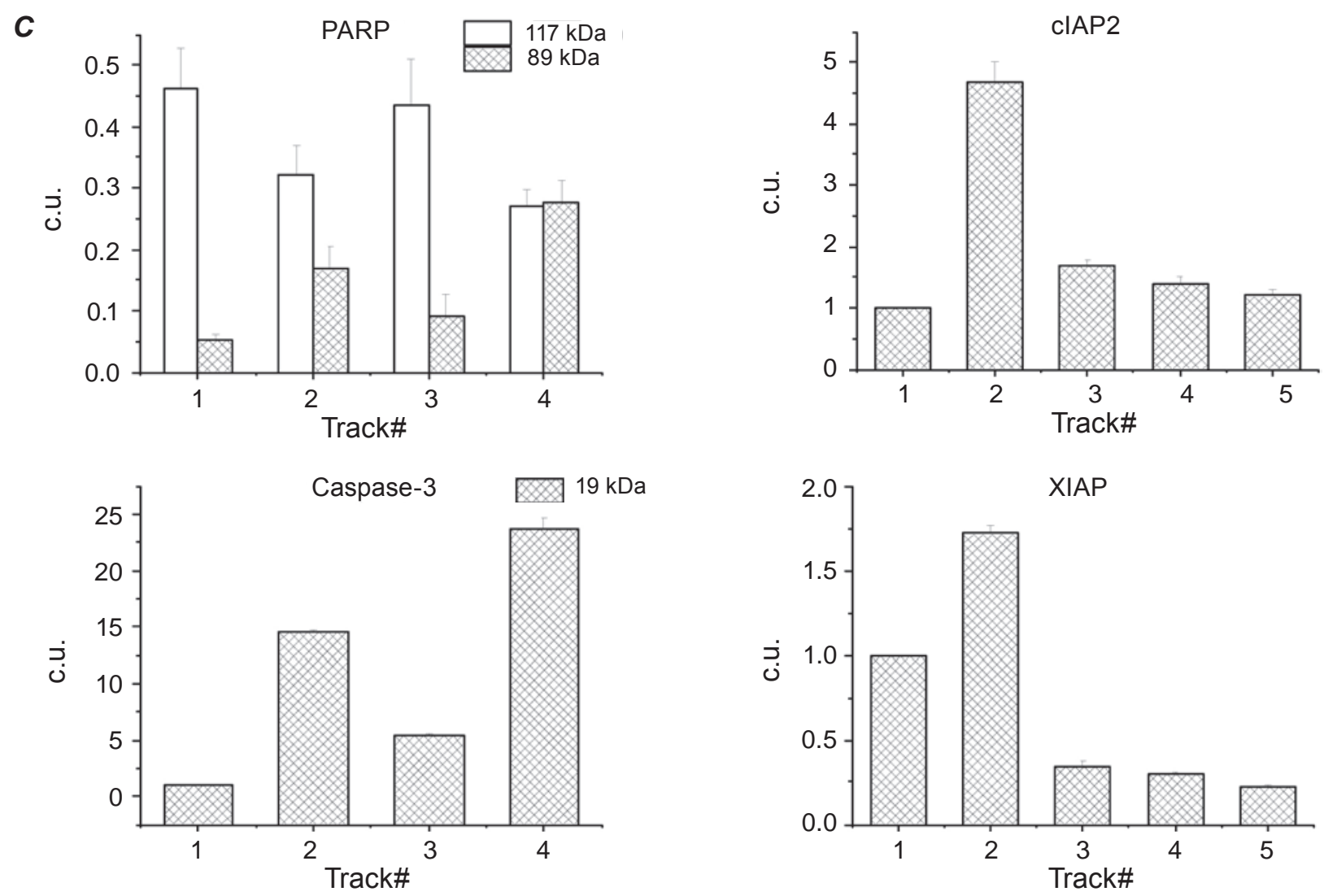

phospho-cRaf-1

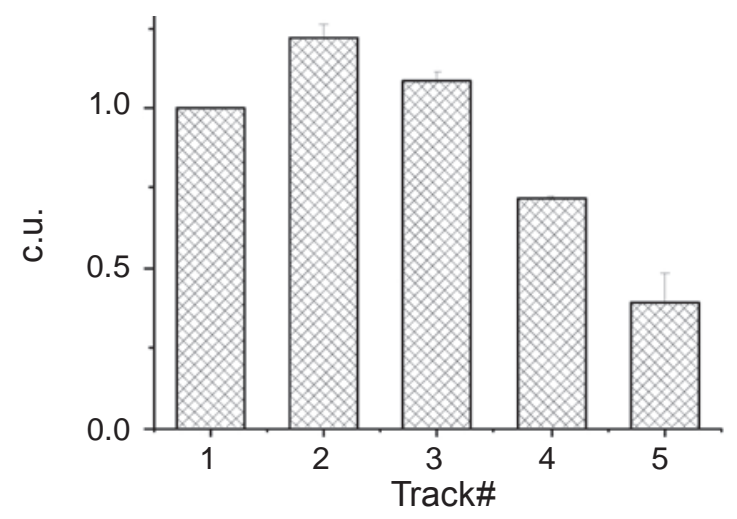

Fig. 2. The effect of the combined action of paclitaxel and $N F-\kappa B$ inhibitor on activation and content of proand antiapoptotic proteins in FRO cells. Diagrams of amount of the pro- and antiapoptotic proteins (C) in cell lysates after data normalization according to $\beta$-actin content in the respective track. c.u. - conventional units. $M \pm S E, n=3$

trations of DHMEQ, protein phosphorylation gradually attenuated, which indicated the kinase inactivation. Thus, one can conclude that NF- $\mathrm{KB}$ activates mitogen-activated protein kinases in anaplastic thyroid carcinoma cells.

The obtained data are interesting because cRaf-1 (MAPKKK) is a component of signaling cascade Ras/Raf/MEK/ERK - the kinase upstream in the regulatory chain of protein kinases MEK1/2 and ERK1/2, which play an important role in control of the proliferative potential, and apoptotic processes in different tissues [19], including transformed cells of the thyroid [20]. We have shown previously that inhibition of this signaling cascade by specific inhibitors enhanced Ptx-induced apoptotic processes [3]. It is known that Ras and associated signaling cascade is 

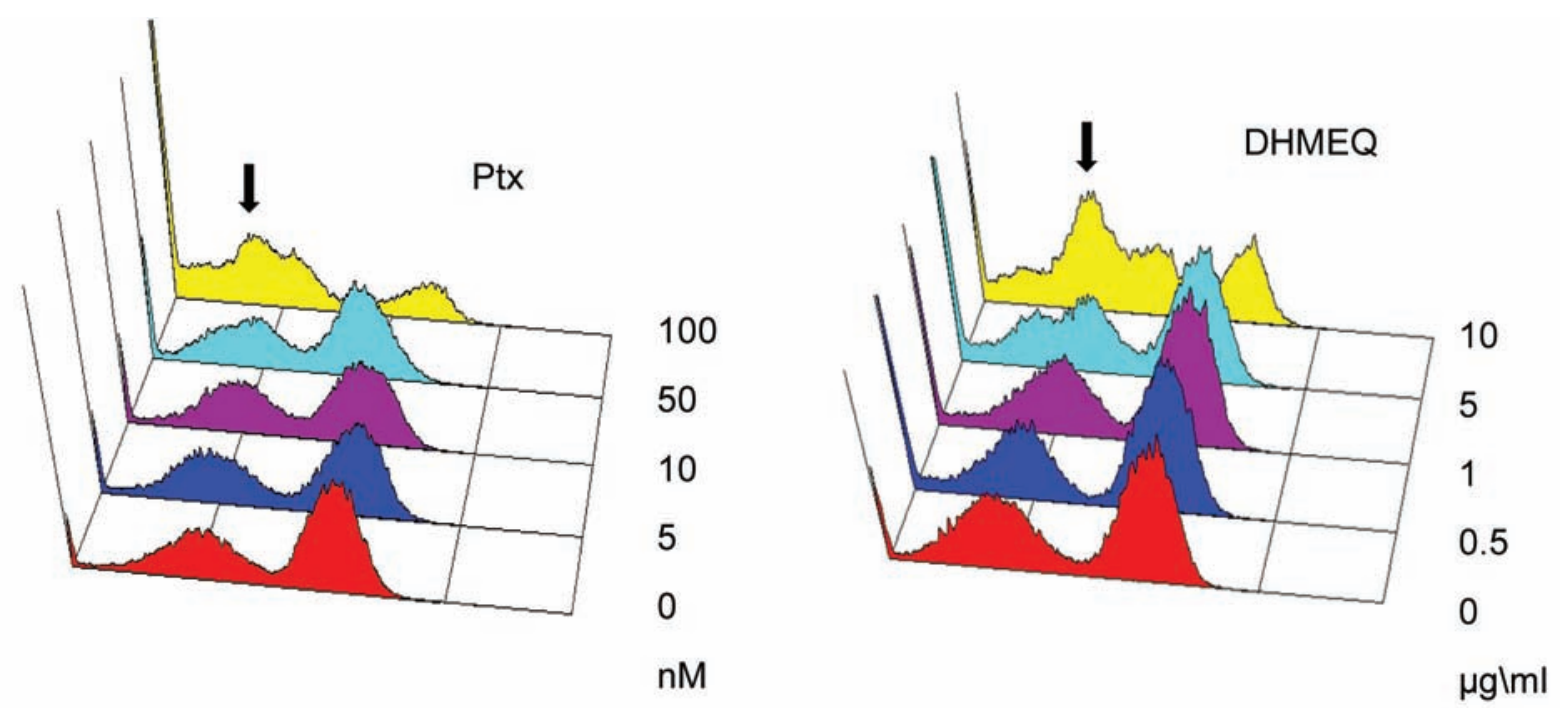

Fig. 3. Effects of paclitaxel and NF- $\kappa B$ inhibitor on mitochondrial membrane potential. $Y$ axis - number of cells; $X-T M R E$ content; arrows show cells with mitochondria that have lost membrane potential

able to activate NF- $\kappa \mathrm{B}$, especially in tumor cells [21], but the reverse effect of factor on this cascade was studied insufficiently. One of possible mechanisms of this activation can be a release of protein kinase TLP2 from the complex, consisting of MAPK/p105subunit of NF- $\kappa$ B/TLP2 [22].

Since NF- $\kappa \mathrm{B}$ is a transcriptional factor that is able to regulate the expression of a number of antiapoptotic proteins, role of MAPK in these processes remains unclear and requires further elucidation. Perhaps MAPK through activation of appropriate transcription factors further enhances survival mechanisms.

Effect of Ptx and DHMEQ on mitochondria. Study of the effect of both drugs on mitochondria showed that Ptx concentrations, which induce classic apoptosis $(5-10 \mathrm{nM})$ did not cause significant changes $\Delta \Psi_{m}$ (Fig. 3). The number of cells with lost mitochondria potential increases at higher Ptx concentrations of $50 \mathrm{nM}$ ( $25.9 \%$ of cells) and, especially, at $100 \mathrm{nM}$ (up to $44.1 \%$ of cells).

The NF- $\kappa B$ inhibitor, DHMEQ, also predetermined loss of mitochondria $\Delta \Psi_{\mathrm{m}}$ in concentration $5 \mu \mathrm{g} / \mathrm{ml}(20.6 \%$ of the cells) and $10 \mu \mathrm{g} / \mathrm{ml}(50.6 \%$ of the cells), and its effect was stronger compared to Ptx (Fig. 3).

Thus, low concentrations of Ptx and DHMEQ do not affect $\Delta \Psi_{\mathrm{m}}$, and high levels of the drugs trigger in thyroid tumor cells processes of necrotic type.

Cell survival determination at Ptx and DHMEQ impact. In in vitro experiments anaplastic thyroid cells incubation with Ptx caused their death (Fig. 4, A). The drug concentrations starting from $2 \mathrm{nM}$ proved effective. A more detailed study of ultralow and low Ptx concentrations showed that the addition of DHMEQ in the medium increased the cytotoxic effect of Ptx, but only in rather narrow range of low concentrations of the drug (0.5-5 nM) (Fig. 4, B).

In subsequent studies we used mutARO cells cell line with a mutation in the gene encoding I $\mathrm{B} \alpha$. As a result of mutations serine residues 32 and 36 are replaced by alanine, and this protein cannot be

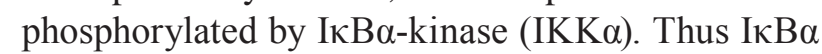
acquires resistance to ubiquitinilation and degradation in proteasomes, which, in turn, causes inhibition of NF- $\kappa$ B activation [17].

Fig. 5, A shows that Ptx cytotoxicity in the cells with IкB $\alpha$ mutation increases at low concentrations of the drug. A more detailed study of Ptx action at low and very low concentrations showed that the increase of Ptx effect is observed only in 1-10 nM concentration range (Fig. 5, B).

Thus, Ptx concentrations starting from $2 \mathrm{nM}$ are effective. It should be noted that the drug concentrations in the range of 2-25 $\mathrm{nM}$ cause apoptosis, whereas higher concentrations lead to cell cycle arrest and necrotic processes [3], which is confirmed by the data presented in Fig. 3. According to the theory of "wounds that do not heal" [23] in tumor treatment it is essential for anticancer drugs to cause not necrosis but apoptosis. Necrosis stimulates supplying of tumor with growth factors, cytokines and 
$\boldsymbol{A}$

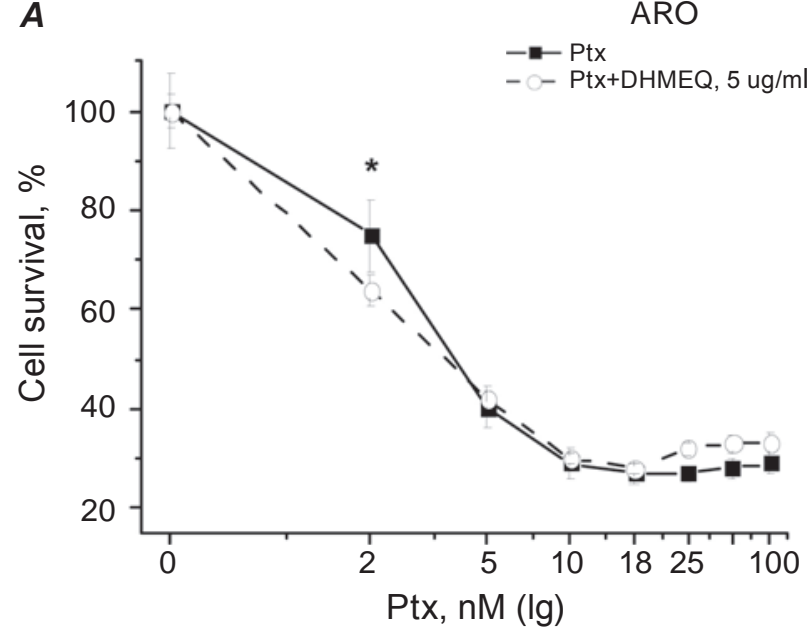

$B$

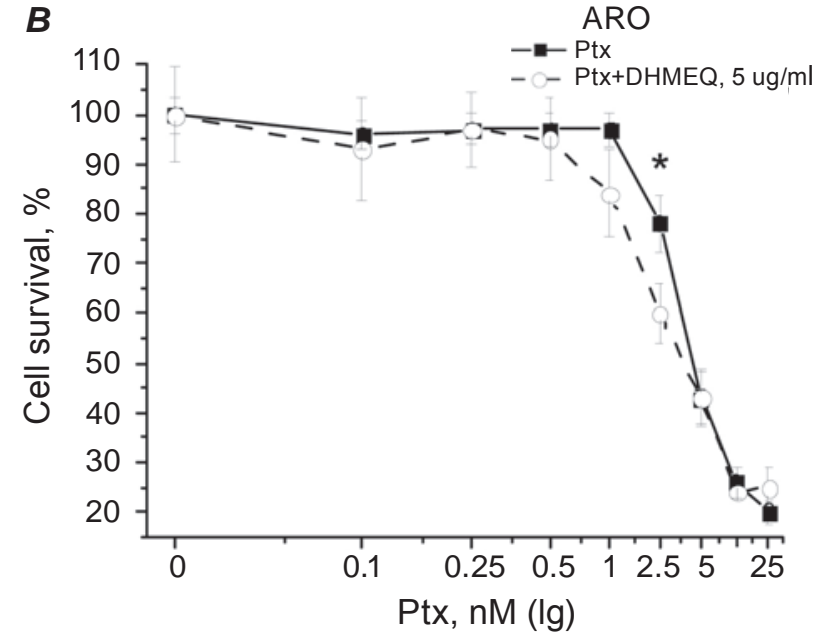

Fig. 4. Effect of paclitaxel and combined action of paclitaxel with the NF- $\kappa B$ inhibitor $(5 \mu \mathrm{g} / \mathrm{ml})$ on ARO cell survival. $M \pm S D ; n=6$; * significant difference between the value of the corresponding point of another curve, $P<0.05$

"building materials", and hence enhances its regeneration and growth.

The practical implication of the results is that lower doses of Ptx, toxicity of which to the whole organism is widely known, can be used in further preclinical and clinical studies of inhibitors of NF- $\mathrm{kB}$ signaling pathway.

Ptx and DHMEQ effect on xenotransplanted tumor. To investigate the effect of Ptx and DHMEQ in vivo, FRO cells ( $5 \times 10^{6}$ cells per animal) were injected s.c. into both flanks of female BALB/c nu/nu mice, and kept until the tumor size reached approximately $100 \mathrm{~mm}^{3}$. Ptx and DHMEQ were injected intraperitoneally. Measurements carried out in 7 days

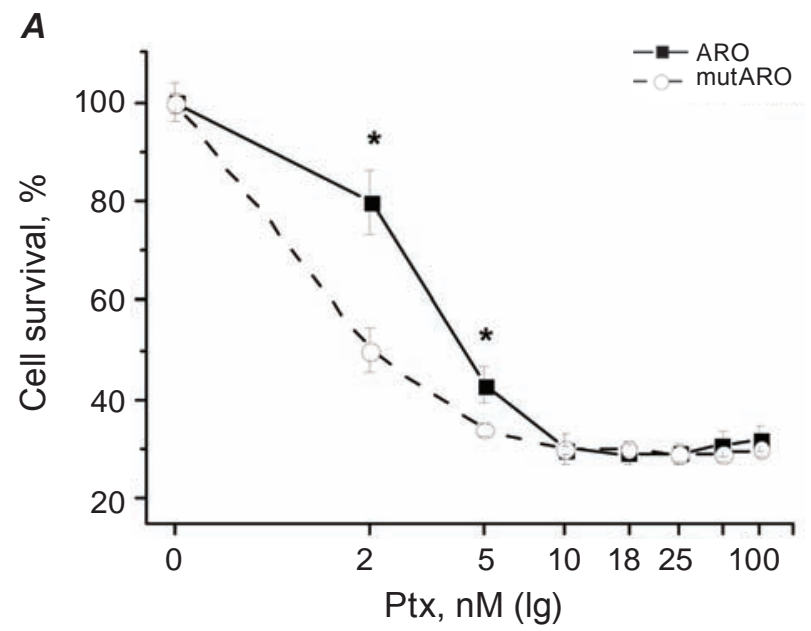

after the start of drug administration showed that in control mice tumor volume had increased about 3.5 times, DHMEQ (8 mg/kg/day) and Ptx (10 mg/kg/ day) significantly inhibited tumor growth, with the latter significantly more effective than NF- $\mathrm{kB}$ inhibitor (Fig. 6). It is important to note that the combined effect of both compounds proved to be significantly more effective compared with the effect of each of these compounds separately (Fig. 6).

In another experiment, concentration of Ptx, injected into mice, was reduced to $2 \mathrm{mg} / \mathrm{kg} /$ day and the experiment was prolonged to 20 days. The Table shows that in control mice tumors grow linearly with time and on the $20^{\text {th }}$ day reach more than 10 -fold size

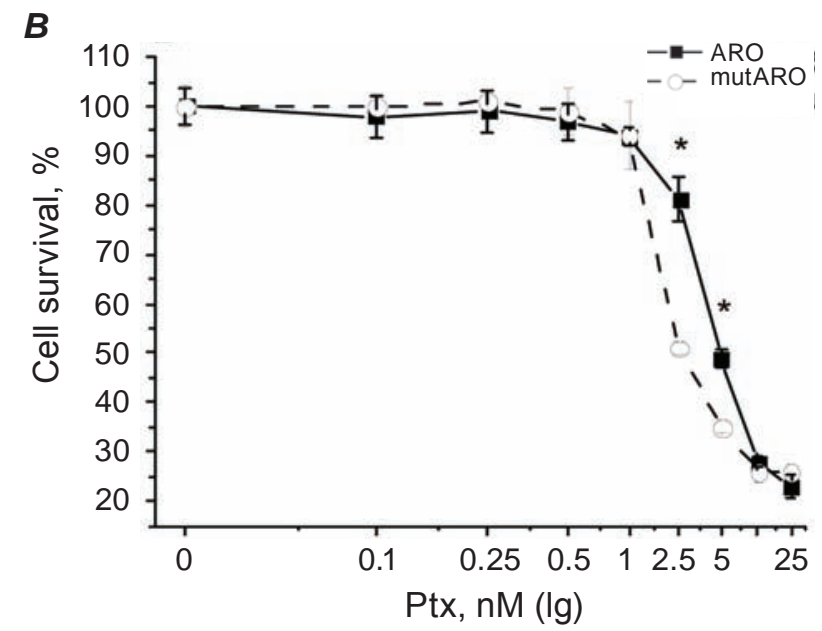

Fig. 5. Comparison of paclitaxel effect on ARO and mutARO cell survival. $M \pm S D ; n=6$; * significant difference between the value of the corresponding point of another curve, $P<0.05$ 


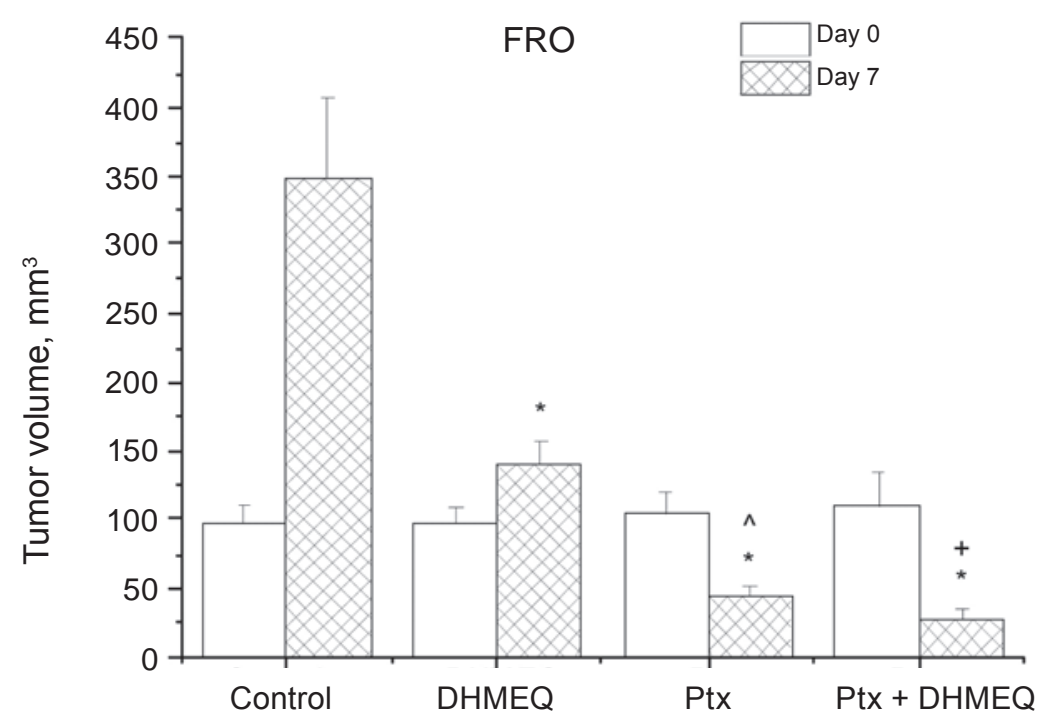

Fig. 6. The effect of paclitaxel and combined action of paclitaxel and NF- $\kappa B$ inhibitor on tumors growth. $M \pm S D ; n=9$; * significant difference from control value, $P<0.05$; ^ difference between the effect of paclitaxel and an NF- $\kappa B$-inhibitor - significant, $P<0.05$; + difference between combined effect of paclitaxel with $D H M E Q$ and effects of these compounds separately - significant, $P<0.05$

The effect of paclitaxel and combined action of paclitaxel and $N F-\kappa B$ inhibitor on tumors growth $(M \pm S D)$

\begin{tabular}{c|c|c|c|c}
\hline Days & Control & DHMEQ & Ptx & DHMEQ + Ptx \\
\hline Control & $100.0 \pm 17.5$ & $100.0 \pm 14.9$ & $100.0 \pm 16.5$ & $100.0 \pm 21.3$ \\
7 day & $422.2 \pm 99.6$ & $280.2 \pm 106.2$ & $86.9 \pm 45.0$ & $23.8 \pm 6.5$ \\
11 day & $602.8 \pm 127.2$ & $334,1 \pm 144.3$ & $22.5 \pm 5.1^{+}$ & $4.6 \pm 1.1^{*}$ \\
16 day & $962.8 \pm 153.0$ & $298.5 \pm 45.2$ & $9.7 \pm 4.8^{+}$ & $0.0^{*}$ \\
20 day & $1087.2 \pm 172.8$ & $569.6 \pm 126.1$ & $7.6 \pm 2.3^{+}$ & $0.0^{*}$ \\
\hline $\mathrm{P}=$ & - & 0.058 & 0.011 & 0.0097 \\
\hline
\end{tabular}

Note: Data are expressed as a percentage; $100 \%$ was the average tumor size in each group $(n=9)$ before drug administration. $P$ - significance of differences from control values. * Difference between combined effect of paclitaxel with DHMEQ and effects of these compounds separately - significant, $P<0.05 ;{ }^{+}$tumor reduction compared with control $\left(100 \mathrm{~mm}^{3}\right)$ significant, $P<0.01$

compared to the initial tumor volume. DHMEQ itself inhibited the tumor growth only about 2 times, while Ptx reduced tumor volume compared to control mice, starting from 11 days of treatment, and on the $16^{\text {th }}$ day the tumor size was reduced to several $\mathrm{mm}^{3}$. A combination of both compounds was even more effective - tumors completely disappeared on day 16 (Table).

In this manner, NF- $\kappa \mathrm{B}$ inhibitor, dehydroxymethylepoxyquinomycin, suppresses the expression of proteins-inhibitors of apoptosis that enhances the cytotoxic effect of paclitaxel in human anaplastic thyroid cancer cells.

NF- $\kappa \mathrm{B}$ transactivates a mitogen-activated signaling cascade that may indicate the existence of an additional antiapoptotic effect mechanism of this transcription factor in anaplastic thyroid cancer cells.

The combination of paclitaxel and NF- $\kappa \mathrm{B}$ inhibitor is a promising option for preclinical studies on the treatment of invasive and radioiodine-resistant forms of thyroid cancer. 


\section{ІНГІБІТОР ТРАНСКРИПЦИЙНОГО ФАКТОРА NF-КВ, DНМЕQ, ПОСИЛЮЄ ДІЮ ПАКЛІТАКСЕЛУ НА КЛІТИНИ АНАПЛАСТИЧНОЇ КАРЦИНОМИ ЩИТОПОДІБНОÏ ЗАЛОЗИ IN VITRO I IN VIVO}

\author{
В. В. Пушкарьов \\ В. М. Пушкарьов ${ }^{1}$, О. I. Ковзунн, \\ М. Д. Тронько
}

\author{
${ }^{1}$ ДУ «Інститут ендокринології та обміну речовин \\ ім. В. П. Комісаренка НАМН України», Київ; \\ e-mail: pushkarev.vm@gmail.com; \\ ${ }^{2}$ Department of Biochemistry, Medical \\ College of Wisconsin, USA; \\ e-mail: dstarenki@mcw.edu
}

Вивчали дію протипухлинного препарату паклітакселу (Ptx) на біохімічні механізми, що регулюють апоптоз у клітинах анапластичної карциноми щитоподібної залози (Щ3). Показано, що поряд з апоптичними процесами, Ptx індукує сигнальні каскади, які забезпечують виживання клітин. Активація паклітакселем ядерного фактора каппа B (NF-кB) призводить до посилення експресії низки антиапоптичних протеїнів, таких як survivin, cIAP та XIAP.

Новий інгібітор NF-кB, дегідроксиметилепоксиквіноміцин (DHMEQ), посилює цитотоксичний ефект Ptx щодо клітин анапластичної карциноми ЩЗ. У клітинах, проінкубованих 3 обома препаратами, спостерігали посилення активації каспази-3 та -9, розщеплення полі(ADP-рибозо)-полімерази (PARP) та зменшення кількості протеїнів-супресорів апоптозу. За підвищених концентрацій Ptx та DHMEQ спостерігали втрату мітохондріями трансмембранного потенціалу $\left(\Delta \Psi_{\mathrm{m}}\right)$.

Пригнічення NF-кB посилює також ефект паклітакселу щодо пухлин, які утворюються шляхом ксенотрансплантації мишам клітин лінії FRO. У тварин, яким вводили одночасно паклітаксел та інгібітор NF-кB, спостерігали зменшення об'єму пухлин, що вірогідно відрізнялося від ефектів кожної зі сполук введених окремо.

Таким чином, комбіноване застосування паклітакселу та інгібітора NF-кB пригнічує біохімічні процеси, що зумовлюють стійкість клітин анапластичної карциноми ЩЗ до дії паклітакселу.
К л ю ч о в і с ло в а: щитоподібна залоза, паклітаксел, NF-кB, анапластична карцинома, апоптоз.

\section{ИНГИБИТОР \\ ТРАНСКРИПЦИОННОГО ФАКТОРА \\ NF-КВ, DНМЕQ, УСИЛИВАЕТ \\ ДЕЙСТВИЕ ПАКЛИТАКСЕЛА НА \\ КЛЕТКИ АНАПЛАСТИЧЕСКОЙ \\ КАРЦИНОМЫ ЩИТОВИДНОЙ \\ ЖЕЛЕЗЫ IN VITRO И IN VIVO}

\section{В. В. Пушкарев ${ }^{1}$, Д. В. Старенькийㄹ, \\ В. М. Пушкарев ${ }^{1}$ Е. И. Ковзун ${ }^{1}$, \\ Н. Д. Тронько}

${ }^{1} Г У$ «Институт эндокринологии и обмена веществ им. В. П. Комиссаренко НАМН Украины», Киев; e-mail: pushkarev.vm@gmail.com;

${ }^{2}$ Department of Biochemistry, Medical College of Wisconsin, USA; e-mail: dstarenki@mcw.edu

Изучали действие противоопухолевого препарата паклитаксела (Ptx) на биохимические механизмы, регулирующие апоптоз в клетках анапластической карциномы щитовидной железы (ЩЖ). Показано, что наряду с апоптическими процессами, Ptx индуцирует сигнальные каскады, которые обеспечивают выживание клеток. Активация паклитакселем ядерного фактора каппа B (NF-кB) приводит к усилению экспрессии ряда антиапоптичных протеинов, таких как survivin, cIAP, XIAP.

Новый ингибитор NF-кB, дегидроксиметилепоксиквиномицин (DHMEQ), усиливает цитотоксический эффект Ptx относительно клеток анапластичной карциномы ЩЖ. В клетках, проинкубированных с двумя исследуемыми препаратами, наблюдали усиление активации каспазы-3 и -9, расщепление поли-(ADP-рибозо) полимеразы (PARP) и уменьшение количества протеинов-супрессоров апоптоза. При повышенных концентрациях Ptx и DHMEQ отмечена потеря митохондриями трансмембранного потенциала $\left(\Delta \Psi_{\mathrm{m}}\right)$.

Угнетение NF-кB усиливало также эффект паклитаксела относительно опухолей, которые образуются путем ксенотрансплантации мышам клеток линии FRO. У животных, которым вводили одновременно паклитаксел и ингибитор NF-кB, наблюдали уменьшение объема опу- 
холей, что достоверно отличалось от эффектов каждого из соединений, введенного отдельно.

Таким образом, комбинированное применение паклитаксела и ингибитора NF-кB подавляет биохимические процессы, обусловливающие устойчивость клеток анапластической карциномы ЩЖ к действию паклитаксела.

К л юче вы е с лов а : щитовидная железа, паклитаксел, NF-кB, анапластическая карцинома, апоптоз.

\section{References}

1. Kingston D. G. I. The shape of things to come: Structural and synthetic studies of taxol and related compounds. Phytochemistry. 2007;68(14):1844-1854.

2. Jordan M. A., Wilson L. Microtubules as a target for anticancer drugs. Nat. Rev. Cancer. 2004;4(4):253-265.

3. Pushkarev V. M., Starenki D. V., Saenko V. A., Namba H., Kurebayashi J., Tronko M. D., Yamashita S. Molecular mechanism of the effects of low concentrations of taxol in anaplastic thyroid cancer cells. Endocrinology. 2004;145(7):3143-3152.

4. Pushkarev V. M., Starenki D. V., Saenko V. O., Tronko M. D., Yamashita S. Effects of paclitaxel and combination of the drug with radiation therapy in an in vivo model of anaplastic thyroid carcinoma. Exp. Oncol. 2011;33(1):24-27.

5. Ghosh S. Handbook of transcription factor NFkappaB. LLC Boca Raton: CRC Press by Taylor \& Francis Group, 2007; 223 p.

6. Hayden M. S., Ghosh S. NF-kB, the first quartercentury: remarkable progress and outstanding questions. Genes. Dev. 2012;26(3):203-234.

7. Karin M. NF-kB as a critical link between inflammation and cancer. Cold Spring Harb. Perspect. Biol. 2009;1(5):a000141.

8. Chaturvedi M. M., Sung B., Yadav V. R., Kannappan R., Agarwal B. B. NF-kB addiction and its role in cancer: 'one size does not fit all'. Oncogene. 2011;30(14):1615-1630.

9. Grivennikov S. I., Greten F. R., Karin M. Immunity, inflammation, and cancer. Cell. 2010;140(6):883-899.

10. Grivennikov S. I., Karin M. Dangerous liaisons: STAT3 and NF-kappaB collaboration and crosstalk in cancer. Cytokine Growth Factor Rev. 2010;21(1):11-19.
11. Nagel D., Vincendeau M., Eitelhuber A. C., Krappmann D. Mechanisms and consequences of constitutive NF-kB activation in B-cell lymphoid malignancies. Oncogene. 2014;33(50):56555665.

12. Altieri D. C. Survivin and IAP proteins in celldeath mechanisms. Biochem. J. 2010;430(2):199205.

13. Winsauer G., Resch U., Hofer-Warbinek R., Schichl Y. M., de Martin R. XIAP regulates bi-phasic NF- $\kappa B$ induction involving physical interaction and ubiquitination of MEKK2. Cell. Signal. 2008;20(11):2107-2112.

14. Gyrd-Hansen M., Meier P. IAPs: from caspase inhibitors to modulators of NF- $\kappa \mathrm{B}$, inflammation and cancer. Nat. Rev. Cancer. 2010;10(8):561574.

15. Pacifico F., Mauro C., Barone C. Crescenzi E., Mellone S., Monaco M., Chiappetta G., Terrazzano G., Liguoro D., Vito P., Consiglio E., Formisano S., Leonardi A. Oncogenic and Antiapoptotic Activity of NF-kB in Human Thyroid Carcinomas. J. Biol. Chem. 2004;279(52):5461054619.

16. Li F., Sethi G. Targeting transcription factor NF-kappaB to overcome chemoresistance and radioresistance in cancer therapy. Biochim. Biophys. Acta. 2010;1805(2):167-180.

17. Starenki D., Namba H., Saenko V. Inhibition of nuclear factor-kB cascade potentiates the effect of a combination treatment of anaplastic thyroid cancer cells. J. Clin. Endocrinol. Metab. 2004;89(1):410-418.

18. Scaduto R. C., Grotyohann L. W. Measurement of mitochondrial membrane potential using fluorescent rhodamine derivatives. Biophys. J. 1999;76(1 Pt 1):469-477.

19. Yang J.-Y., Zong C. S., Xia W. Yamaguchi H., Ding Q., Xie X., Lang J. Y., Lai C. C., Chang C. J., Huang W. C., Huang H., Kuo H. P., Lee D. F., Li L. Y., Lien H. C., Cheng X., Chang K. J., Hsiao C. D., Tsai F. J., Tsai C. H., Sahin A. A., Muller W. J., Mills G. B., Yu D., Hortobagyi G. N., Hung M. C. ERK promotes tumorigenesis by inhibiting FOXO3a via MDM2-mediated degradation. Nat. Cell Biol. 2008;10(2):138-148.

20. Xing M. Molecular pathogenesis and mechanisms of thyroid cancer. Nat. Rev. Cancer. 2013;13(3):184-199. 
21. Duran A., Linares J. F., Galvez A. S. Wikenheiser K., Flores J. M., Diaz-Meco M. T., Moscat J. The Signaling Adaptor p62 Is an Important NF-kB Mediator in Tumorigenesis. Cancer Cell. 2008;13(4):343-354.

22. Lawrence M. C., Jivan A., Shao C. Duan L., Goad D., Zaganjor E., Osborne J., McGlynn K.,
Stippec S., Earnest S., Chen W., Cobb M. H. The roles of MAPKs in disease. Cell Res. 2008;18(4):436-442.

23. Luchnik A.N. A model of self-maintenance of in vivo malignant growth not dependent on tumour type or origin: syndrome of everlasting wound healing. Cancer Biol. Ther. 2003;2(4):343-346.

Received 08.10.2014 